\title{
Pengaruh Penerapan Manajemen Risiko Terhadap Kinerja Keuangan Triwulan 2016 - 2020 Pada Bank Pembangunan Daerah Jawa Timur
}

\author{
Harun Al Rasyid ${ }^{1 *}$, Syukron Sazly ${ }^{2}$ \\ Universitas Bina Sarana Informatika ${ }^{12}$ \\ Harun.har@bsi.ac.id, syukron.szy@bsi.ac.id
}

\author{
*Penulis Korespondensi \\ Dikirim : 7 Mei 2021 \\ Diterima : 27 Juli 2021 \\ Dipublikasikan : 1 Agustus 2021
}

\begin{abstract}
Importance The role of banking is currently very dominant with the financial system. A good financial system will have a positive effect on banking performance. This study aims to determine the effect of banking risk which is analyzed using the ratio of NPL, NIM, LDR, BOPO on financial performance with ROA at the Regional Development Bank of East Java. The data used in this study were obtained from annual published financial reports from the website ojk.go.id. The number of samples is 20 East Java Regional Development Banks with a quarterly period from 2016-20202. This study uses the SSS method where the results of the research show that the determinant coefficient (R2) shows the Adjusted R Square number of 0.988 or $98.8 \%$, which means that variations in the level of financial performance can be explained by NPL, NIM, LDR and BOPO on ROA, the remaining $1.2 \%$ can be explained from other variables outside the research variables. For the research results simultaneously, NPL, NIM, LDR, and BOPO have a significant effect on ROA. The effect partially for NPL Risk (XI) does not have a significant negative effect partially on ROA (Y), for NIM risk (X2) has a partially significant positive effect on ROA (Y), for LDR risk (X3) does not have a significant negative effect partial to the level of ROA (Y), and for the risk of OEOI (X4) a significant negative effect partially on the level of ROA (Y). It is better if the Regional Development Bank of East Java, must be able to identify the risks that may occur in its business activities. In connection with the results of research where the Bank must minimize NPL, LDR and OEOI ratio because it has a negative effect on ROA. Then maximize NIM because it has a positive effect on ROA.
\end{abstract}

Keywords: NPL, NIM, LDR, BOPO, ROA

\section{PENDAHULUAN}

Istilah perbankan sudah tidak asing lagi bagi masyarakat umumnya bagi yang sudah pernah menggunakan jasa perbankan(Ismail, 2016). Istilah perbankan berasal dari kata "bank" yaitu badan usaha yang menghimpun dana dari masyarakat dalam bentuk simpanan dan mengeluarkannya kepada masyarakat dalam bentuk kredit(Sukmawati \& Purbawangsa, 2016). Atau bank adalah suatu badan usaha yang tugas utamanya sebagai lembaga perantara keuangan (financial intermediaries), yang menyalurkan dana dari pihak yang kelebihan dana (surplus) kepihak yang kekurangan dana (deficit) pada waktu yang ditentukan(Purwanto, 2016). Jadi perbankan adalah lembaga yang berfungsi sebagai lembaga intermediasi antara pihak yang surplus dana dengan deficit dana(Probowati, 2020).

Istilah risiko adalah akibat yang kurang menyenangkan (merugikan, membahayakan) dari suatu perbuatan atau tindakan. Sedangkan dalam kamus manajemen, risiko adalah ketidakpastian yang mengandung kemungkinan kerugian dalam bentuk harta atau kehilangan keuntungan atau kemampuan ekonomis(Handa Gustiawan, 2019). Selain itu, risiko dapat dikatakan sebagai suatu peluang terjadi kerugian atau kehancuran. Pengertian risiko yang lebih luas, yaitu sebagai ancaman 
atau kemungkinan suatu tindakan atau kejadian yang menimbulkan dampak yang berlawanan dengan tujuan yang ingin dicapai(Ardhariksa Zukhruf Kurniullah, 2021). Bank Indonesia sendiri memberikan defenisi risiko yang tertuang dalam PBI sebagai potensi terjadinya suatu peristiwa (events) yang dapat menimbulkan kerugian Bank(Zuhri, 2018).

Risiko sering dikatakan sebagai uncertainty atau ketidakpastian. Ketidakpastian sering diartikan dengan keadaan dimana ada beberapa kemungkinan kejadian dan setiap kejadian akan menyebabkan hasil yang berbeda(Solissa, 2017). Tetapi, tingkat kemungkinan atau probabilitas kejadian itu sendiri tidak diketahui secara kuantitatif(Lepar, Mandagi, \& Lumeno, 2018). Sedangkan pengertian dasar risiko terkait dengan adanya ketiakpastiannya terukur secara kuantitatif. Dengan demikian dapat kita simpulkan bahwa risiko adalah peluang dari kemungkinan terjadinya peristiwa yang tidak diinginkan (merugikan) baik bagi perusahaan/lembaga, maupun bagi orang per orang(Ardhariksa Zukhruf Kurniullah, 2021).

Manajemen risiko adalah mengindentifikasi, mengukur, memantau dan mengendalikan jalannya kegiatan usaha bank dengan tingkat risiko yang wajar secara terarah, terintegrasi dan berkesinambungan.11 Manajemen risiko adalah proses pengukuran atau penilaian risiko serta pengembangan strategi pengelolaannya(Suwinardi, 2016). Penerapan manajemen risiko dan prediksi risiko dapat membantu perusahaan menghemat pengeluaran sekaligus melindungi masa depan. Sebab rencana manajemen risiko yang tepat akan membantu perusahaan menetapkan prosedur untuk menghindari ancaman, meminimalkan dampak negatif, serta mengatasi ancaman tersebut(Dewi, 2019). Penerapan manajemen risiko memang dapat menjadi praktik yang sangat bermanfaat bagi perusahaan. Namun, batasan-batasannya tetap harus dipertimbangkan(ILO, 2009). Banyak teknik analisis risiko yang bisa dilakukan untuk mencermati batasan manajemen risiko, seperti membuat model atau simulasi yang membutuhkan pengumpulan data dalam jumlah besar(Zubaidi et al., 2018). Pengumpulan data ekstensif biasanya relatif mahal dan keandalannya belum dapat dipastikan. Penggunaan data dalam proses pengambilan keputusan mungkin menunjukkan hasil buruk jika indikator sederhana digunakan untuk mencerminkan realitas situasi yang jauh lebih kompleks(Suryani, 2018).

\section{Penelitian Terdahulu}

\section{STUDI LITERATUR}

Penelitian ini bertujuan untuk mengetahui pengaruh Risiko Perbankan yang dianalisis dengan menggunakan Rasio NPL, NIM, LDR, BOPO terhadap kinerja keuangan pada Bank Pembangunan Daerah se- Indonesia. Penelitian ini menggunakan metode spss dimana hasil penelitiannya menunjukan bahwa secara simultan, NPL, NIM, LDR, dan BOPO berpengaruh signifikan terhadap ROA. Dan secara parsial, NPL signifikan dan berpengaruh negatif terhadap ROA, NIM signifikan dan berpengaruh Positif terhadap ROA, LDR tidak signifikan dan berpengaruh negatif terhadap ROA, BOPO signifikan dan berpengaruh negatif terhadap ROA. Lewat penelitian ini diketahui bahwa Risiko Perbankan yang diukur lewat empat rasio yang ada memiliki pengaruh yang signifikan terhadap kinerja keuangan (ROA)(Kansil et al., 2017).

Tujuan penelitian ini adalah untuk menguji pengaruh Non Performing Loan (NPL), Net Interest Margin (NIM), Loan to Deposit Ratio (LDR) dan Biaya Operasional Pendapatan Operasional (BOPO) terhadap Return on Assets (ROA) pada Pembangunan Daerah. Bank (BPD) di Indonesia. Data yang digunakan dalam penelitian ini adalah data NPL, NIM, LDR, BOPO dan ROA dari BPD di Indonesia dari tahun 2011 sampai 2016 yang diakses melalui website www.ojk.go.id. Metode analisis data dalam penelitian ini adalah analisis regresi linier berganda. Hasil penelitian menemukan bahwa NPL dan NIM tidak berpengaruh signifikan terhadap ROA, sedangkan LDR dan BOPO berpengaruh negatif(Nazir \& Mahfuzah, 2018).

Penelitian ini bertujuan untuk menganalisis Pengaruh Penerapan Manajemen Risiko Terhadap Kinerja Keuangan Dengan Dimoderasi Good Corporate Governance (Studi Empiris Pada Bpd SeIndonesia Tahun 2009-2013). Variabel independen yang digunakan dalam penelitian ini adalah penerapan manajemen risiko yang diwakili oleh manajemen risiko kredit (NPL), manajemen risiko likuiditas (LDR), dan manajemen risiko operasional (BOPO), sedangkan variabel dependen yang digunakan dalam penelitian ini adalah kinerja keuangan Bank Pembangunan Daerah (ROA), dimoderasi oleh Good Corporate Governance yang terdiri dari ukuran dewan komisaris, komposisi 
dewan komisaris, frekuensi rapat, ukuran komite manajemen risiko dan ukuran komite audit. Sampel penelitian dalam penelitian ini terdiri dari 13 BPD yang terdaftar Se-indonesia pada periode penelitian 2009-2013 yang dipilih berdasarkan kriteria tertentu dengan menggunakan metode purposive sampling(Suci Izdihar, 2017).

\section{METODE}

Kerangka teoritis adalah identifikasi teori-teori yang dijadikan sebagai landasan berfikir untuk melaksanakan suatu penelitian atau dengan kata lain untuk mendiskripsikan kerangka referensi atau teori yang digunakan untuk mengkaji permasalahan(Iwan Hermawan, 2019). Biasanya kerangka teori disusun dalam bentuk matriks, diagram atau gambar sederhana. Berikut ini adalah proses penelitian kuantitatif yang terdiri dari beberapa proses seperti yang dijelaskan di bawah ini:

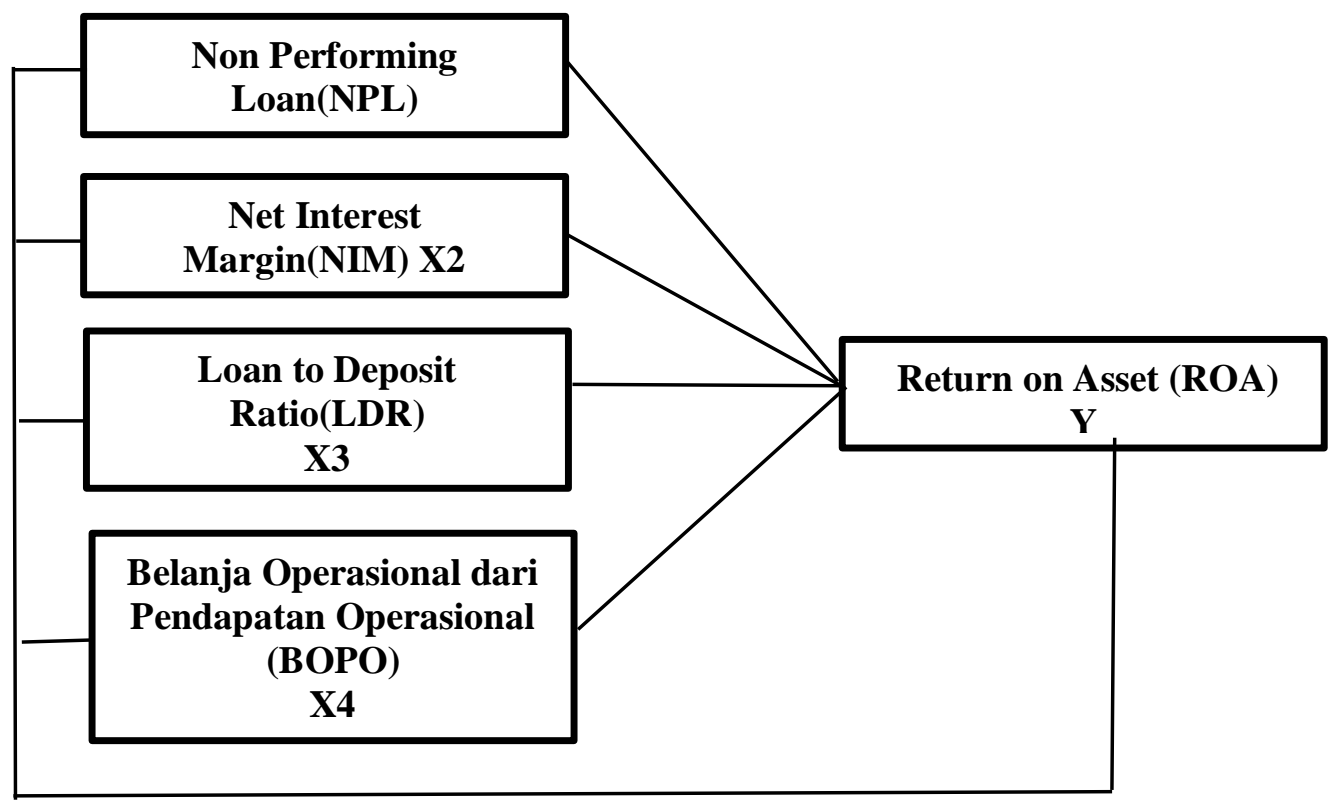

Gambar 1. Kerangka Teoritis

Sumber gambar : Data Penelitan,2021

Pada Gambar 1. Pendekatan yang digunakan adalah kuantitatif dengan format deskriptif, karena bertujuan untuk menjelaskan dan menceritakan berbagai situasi dan kondisi, atau berbagai variabel yang menjadi objek penelitian berdasarkan apa yang terjadi. Dalam penelitian ini akan dibahas pengaruh $\mathrm{NPL}(\mathrm{X} 1), \mathrm{NIM}(\mathrm{X} 2), \mathrm{LDR}(\mathrm{X} 3), \mathrm{BOPO}(\mathrm{X} 4)$ terhadap tingkat $\mathrm{ROA}(\mathrm{Y})$.

1. Tinjauan pustaka

Referensi penelitian peneliti berupa buku, artikel jurnal yang berkaitan dengan manajemen risiko pada tingkat kinerja keuangan di Bank, regresi linier berganda untuk dijadikan kajian teoritis dalam penelitian.

2. Pengumpulan data

Populasi adalah wilayah generalisasi yang terdiri atas objek / subjek yang mempunyai besaran dan karakteristik tertentu yang diterapkan oleh penelitian untuk dipelajari dan kemudian ditarik kesimpulannya. Jadi populasi dalam penelitian ini adalah Keuangan Triwulan (Maret, Juni, September dan Desember) 2016-2020 PT Bank Pembangunan Daerah Jawa Timur(OJK, 2021).

Sampel adalah bagian dari jumlah dan karakteristik yang dimiliki oleh populasi tersebut . Dalam penelitian ini tidak diterbitkan laporan keuangan Triwulanan (Maret, Juni, September dan Desember) Bank Pembangunan Daerah Jawa Timur periode 2016-2020 , untuk laporan keuangan (Khasanah \& Pertiwi, 2010) triwulan Maret 2016 tidak diterbitkan, triwulan September 2017 tidak diterbitkan, yang berarti terdapat 22 sampel.

Definisi operasional dilakukan agar tidak terjadi penyimpangan dalam membahas dan menganalisis permasalahan penelitian yang dilakukan. Definisi operasional variabel dalam penelitian ini adalah(Ridha, 2017):

Variabel terikat (dependent variable) adalah variabel yang nilainya dipengaruhi oleh variabel lain. Variabel terikat penelitian ini adalah tingkat kinerja bank adalah ROA(Y). Dalam penelitian 
ini variabel dependen diukur dengan Return on Asset(ROA) yaitu jumlah level ROA di PT Bank Pembangunan Daerah Jawa Timur periode 2016-2020 yang diperoleh dari laporan keuangan Triwulanan (Maret, Juni, September dan Desember) PT Bank Pembangunan Daerah Jawa Timur.Untuk variabel bebas terdiri dari variabel Non Performing Loan (X1), variabel Net Interest Margin (X2), variabel Loan to Deposit Ratio (X3) dan variabel Belanja Operasional dari Pendapatan Operasional(X4).

Penelitian ini menggunakan metode data kuantitatif, dimana data yang digunakan dalam penelitian berupa angka dan perhitungan menggunakan metode statistik berbantuan program SPSS 21. Pengumpulan data bersumber dari lembaga keuangan OJK (Otoritas Jasa Keuangan) untuk laporan Publikasi di PT Bank Pembangunan Daerah Jawa Timur Triwulan (Maret, Juni, September dan Desember) dari 2016 - 2020(OJK, 2021).

Tabel 1. Laporan Keuangan PT Bank Pembangunan Daerah Jawa Timur 2016-2020

\begin{tabular}{|l|l|l|l|l|l|l|}
\hline $\begin{array}{l}\text { TAHU } \\
\mathrm{N}\end{array}$ & TRIWULAN & $\begin{array}{l}\text { Risiko } \\
\text { pembiaya } \\
\text { an ( NPL) }\end{array}$ & $\begin{array}{l}\text { Net } \\
\text { Interest } \\
\text { Margin } \\
\text { (NIM) }\end{array}$ & $\begin{array}{l}\text { Loan to } \\
\text { Deposit } \\
\text { Ratio } \\
\text { (LDR) }\end{array}$ & $\begin{array}{l}\text { Belanja } \\
\text { Operasional } \\
\text { dari } \\
\text { Pendapatan } \\
\text { Operasional } \\
\text { (BOPO) }\end{array}$ & $\begin{array}{l}\text { Return } \\
\text { on Asset } \\
\text { (ROA) }\end{array}$ \\
\hline \multirow{4}{*}{2016} & MARET & 0 & 0 & 0 & 0 & 0 \\
\cline { 2 - 7 } & JUNI & 4.58 & 6.69 & 72.64 & 70.56 & 3.18 \\
\cline { 2 - 7 } & SEPTEMBER & 4.92 & 6.70 & 71.97 & 71.13 & 3.09 \\
\cline { 2 - 7 } & DESEMBER & 4.77 & 6.94 & 90.48 & 72.22 & 2.98 \\
\hline \multirow{4}{*}{2017} & MARET & 4.84 & 7.18 & 70.62 & 62.62 & 3.96 \\
\cline { 2 - 7 } & JUNI & 4.80 & 6.99 & 72.26 & 61.83 & 4.01 \\
\cline { 2 - 7 } & SEPTEMBER & 0 & 0 & 0 & 0 & 0 \\
\cline { 2 - 7 } & DESEMBER & 4.59 & 6.68 & 79.69 & 68.63 & 3.12 \\
\hline \multirow{4}{*}{2018} & MARET & 4.84 & 6.57 & 69.80 & 59.89 & 3.88 \\
\cline { 2 - 7 } & JUNI & 4.79 & 6.41 & 64.86 & 61.40 & 3.67 \\
\cline { 2 - 7 } & SEPTEMBER & 4.25 & 6.38 & 0.00 & 64.86 & 3.38 \\
\cline { 2 - 7 } & DESEMBER & 3.75 & 6.37 & 66.57 & 69.45 & 2.96 \\
\hline \multirow{3}{*}{2019} & MARET & 3.46 & 6.52 & 65.02 & 62.70 & 3.63 \\
\cline { 2 - 7 } & JUNI & 3.16 & 6.30 & 60.02 & 63.47 & 3.50 \\
\cline { 2 - 7 } & SEPTEMBER & 2.89 & 6.20 & 61.64 & 66.54 & 3.18 \\
\cline { 2 - 7 } & DESEMBER & 2.77 & 6.11 & 63.34 & 71.40 & 2.73 \\
\hline \multirow{3}{*}{2020} & MARET & 3.35 & 6.05 & 66.50 & 64.95 & 3.23 \\
\cline { 2 - 7 } & JUNI & 4.27 & 5.79 & 61.21 & 68.96 & 2.73 \\
\cline { 2 - 7 } & SEPTEMBER & 4.49 & 5.70 & 57.88 & 70.25 & 2.57 \\
\cline { 2 - 7 } & DESEMBER & 4.00 & 5.55 & 60.58 & 77.76 & 1.95 \\
\hline
\end{tabular}

Sumber tabel: Data OJK, 2021

Pada Tabel 1. Laporan yang dipublikasikan untuk publik adalah Triwulanan dari 2016 - 2020, dengan catatan tidak ada laporan Triwulanan Maret 2016 dan Triwulan September 2017, sehingga sampel yang diambil untuk mengolah datanya adalah $\mathrm{N}=18$.

3. Analisis data

Analisis data yang dilakukan oleh penelitian ini terhadap data tersebut adalah sebagai berikut:

a. Uji asumsi klasik

Uji asumsi klasik digunakan untuk mendapatkan model regresi yang menghasilkan estimator linier tidak biasa terbaik atau BLUE (Best Linear Un] Estimator). BIRU dapat dicapai jika memenuhi asumsi klasik. Dalam penelitian uji asumsi klasik yang digunakan adalah uji normalitas, uji multikolonieritas, uji heteroskedastisitas, uji autokorelasi(Zainuddin, 2016).

b. Uji Regresi Linier Berganda

Analisis linier berganda digunakan untuk memprediksi bagaimana keadaan (naik turunnya) 
variabel dependen, ketika dua atau lebih variabel independen sebagai faktor prediktor dimanipulasi (kenaikan dan penurunan nilai)(Rahadjeng, 2017).

c. Pengujian hipotesis

Pengujian hipotesis meliputi:

1) Uji Koefisien Determinan (R2)

Koefisien determinasi digunakan untuk mengetahui persentase hubungan antara independent dan dependent ariable. Besarnya persentase pengaruh semua variabel terhadap nilai dependen ariable dapat dilihat dari besarnya koefisien determinan (R2) persamaan regresi(Manik, 2017).

2) Uji Parsial (Uji t)

Uji $\mathrm{t}$ digunakan untuk menguji apakah masing-masing variabel independen (independen) secara individual maupun individual berpengaruh signifikan terhadap variabel dependen (dependen) pada tingkat signifikan 0,05 (5\%) dengan asumsi variabel independen konstan(Indah Azhari, Junaid, \& Tjan, 2020).

3) Uji Simultan (Uji f).

Uji f digunakan untuk mengetahui pengaruh risiko pembiayaan, risiko operasional dan risiko likuiditas terhadap tingkat efisiensi bank. Uji f pada dasarnya menunjukkan apakah semua variabel bebas atau bebas yang dimasukkan dalam model memiliki pengaruh bersama terhadap variabel terikat atau terikat. Dengan kriteria uji F tabel, jika Fhitung < Ftabel maka H0 diterima dan Ha ditolak artinya tidak signifikan dan jika Fhitung> Ftabel maka H0 ditolak dan Ha diterima, artinya signifikan(Danar Maharudin, 2019).

\section{HASIL}

Pembahasan hasil penelitian meliputi beberapa ujian statistik, diantaranya sebagai berikut:

1. Uji asumsi klasik adalah persyaratan statistik yang harus dipenuhi pada analisis regresi linear berganda yang berbasis ordinary least square (OLS). Uji asumsi klasik juga tidak perlu dilakukan untuk analisis regresi linear yang bertujuan untuk menghitung nilai pada variabel tertentu

Pengujian Asumsi Klasik terdiri dari beberapa pengujian, yaitu:

a. Sebuah Uji normalitas adalah sebuah uji yang dilakukan dengan tujuan untuk menilai sebaran data pada sebuah kelompok data atau variabel, apakah sebaran data tersebut berdistribusi normal ataukah tidak normal.

Model regresi dikatakan berdistribusi normal, jika data titik-titik yang menggambarkan data sesungguhnya mengikuti garis diagonal.

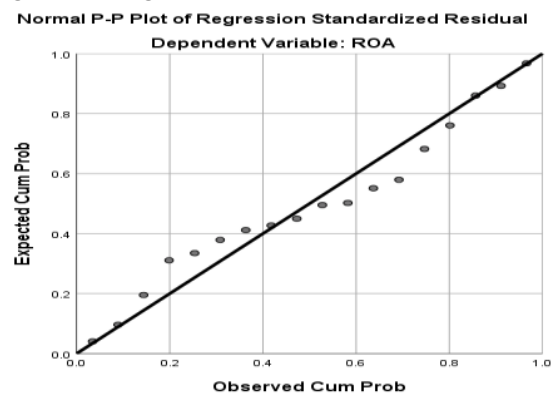

Gambar 2. Uji Normalitas

Sumber data : Data Penelitian,2021

Pada gambar 2. Data titik-titik yang menggambarkan data sesunggunya mengikuti garis normal, dikarenakan penyebaran merata dari titik-titik diatas dan dibawah mengikuti garis diagonal, sehigga model regresi berdistribusi Normal.

b. Uji Multikolonieritas

Uji Multikolonieritas dalah uji yang dilakukan untuk memastikan apakah di dalam sebuah model regresi ada interkorelasi atau kolinearitas antar variabel bebas. Uji multikolonieritas merupakan pengujian untuk mengetahui ada tidaknya hubungan yang signifikan antara variabel independen dalam model regresi linier berganda. Pengujian ini diperlukan untuk mengetahui apakah ada variabel lain dalam satu model atau tidak. Kesamaan antar variabel 
independen dalam suatu model akan menyebabkan korelasi yang sangat kuat antara variabel independen dengan variabel independen lainnya.

Tabel 2. Uji Multikolonieritas

\begin{tabular}{|c|c|c|c|c|c|c|c|c|}
\hline \multicolumn{9}{|c|}{ Coefficients $^{\mathrm{a}}$} \\
\hline \multirow[t]{2}{*}{$\begin{array}{l}\text { Mod } \\
\text { el }\end{array}$} & & & & $\begin{array}{c}\text { Standa } \\
\text { rdized } \\
\text { Coeffi } \\
\text { cients }\end{array}$ & $\mathrm{t}$ & Sig. & $\begin{array}{c}\text { Collin } \\
\text { earity } \\
\text { Statist } \\
\text { ics }\end{array}$ & \\
\hline & & & & Beta & & & $\begin{array}{c}\text { Tolera } \\
\text { nce }\end{array}$ & VIF \\
\hline 1 & $\begin{array}{l}\text { (Constan } \\
\text { t) }\end{array}$ & 5,482 & 0,405 & & 13,538 & 0,000 & & \\
\hline & $\begin{array}{l}\text { NPL(X1 } \\
\text { ) }\end{array}$ & $-0,012$ & 0,022 & $-0,016$ & $-0,521$ & 0,611 & 0,757 & 1,322 \\
\hline & $\operatorname{NIM}(X 2$ & 0,514 & 0,044 & 0,434 & 11,747 & 0,000 & 0,527 & 1,898 \\
\hline & LDR(X3 & 0,000 & 0,001 & $-0,012$ & $-0,406$ & 0,691 & 0,796 & 1,257 \\
\hline & $\begin{array}{l}\mathrm{BOPO}(\mathrm{X} \\
4)\end{array}$ & $-0,082$ & 0,004 & $-0,734$ & $-23,131$ & 0,000 & 0,715 & 1,399 \\
\hline
\end{tabular}

Sumber tabel : Data Penelitian,2021

Pada tabel 2, untuk Uji Multikolonieritas terdapat 2 kondisi, apabila nilai Variance Inflation Factor(VIF) < 10.00 dan Tolerance >0,100 maka tidak terjadi gejala multikolonieritas. Berdasarkan tabel data untuk kondisi VIF adalah : NPL $(1,322<10.00)$, NIM $(1,898<$ $10,00), \operatorname{LDR}(1,257<10,00)$ dan BOPO $(1,399<10,00)$ dan untuk kondisi Tolerance adalah NPL $(0,757>0,100)$, NIM $(0,527>0,100)$, LDR $(0,796>0,100)$, dan BOPO $(0,715>$ $0,100)$, maka kesimpulannya tidak terjadi gejala multikolonieritas.

c. Uji Heteroskedastisitas

Uji heteroskedastisitas adalah suatu kondisi dimana varians error confounding tidak konstan untuk semua nilai variabel independen, dimana pengujian ini bertujuan untuk menguji apakah model regresi tidak memiliki kesamaan varian residual atau observasi lainnya.

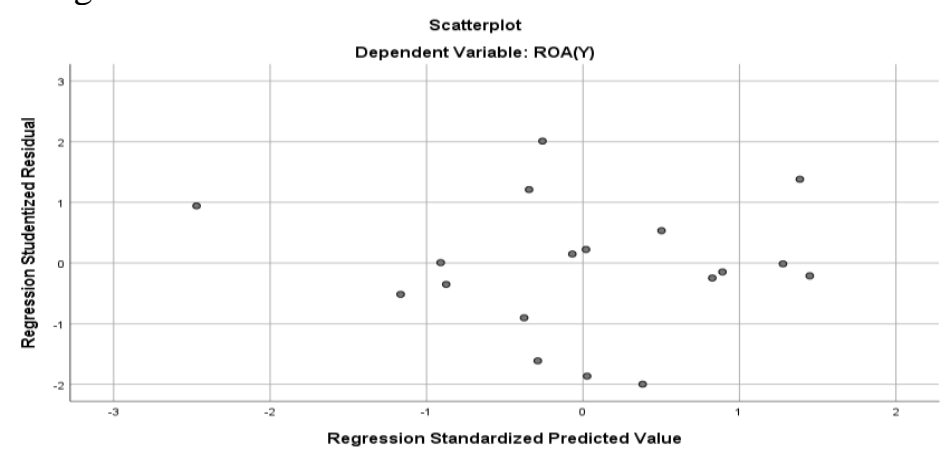

Gambar 3. Model Scatterplot

Sumber gambar : Data Penelitian,2021

Dari gambar 3, ciri-ciri citra model scatterplot adalah:

1) Titik data tersebar di atas dan di bawah atau di sekitar 0.

2) Titik data tidak hanya menggumpal ke atas atau ke bawah.

3) Titik penyebaran data tidak boleh membentuk pola bergelombang yang melebar kemudian menyempit dan melebar kembali.

4) Distribusi titik data tidak boleh berpola.

Sehingga dapat disimpulkan bahwa karakteristik terpenuhi sehingga dapat dikatakan bahwa dalam model regresi pengaruh risiko pembiayaan, risiko operasional dan risiko likuiditas terhadap tingkat efisiensi bank tidak terjadi heteroskedastisitas sehingga dalam uji asumsi 
klasik heteroskedastisitas. terpenuhi. selanjutnya dalam hal ini dapat dilanjutkan ke tahap pengujian regresi linier berganda.

d. Uji Autokorelasi

Uji autokorelasi digunakan untuk melihat apakah terdapat hubungan linier atau kesalahan dalam rangkaian pengamatan yang diurutkan menurut waktu (data deret waktu). Pengujian ini dilakukan jika data yang dianalisis adalah data deret waktu. Untuk melihat apakah ada penyakit autokorelasi. Tes yang sering digunakan adalah tes Durbin-Waston (DW test). Selain menggunakan uji Durbin-Waston, dapat juga digunakan uji korelasional seri Breusch Goldfrey pada Uji LM. Langkah-langkah pengujiannya adalah sebagai berikut:

Hipotesa

H0: Model memiliki autokorelasi

Ha: Model tidak memiliki autokorelasi

Jika probabilitas > Alpha $(0,05)$ maka $\mathrm{H} 0$ ditolak, maka Ha diterima

Jika probabilitas < Alpha $(0,05)$ maka Ha ditolak maka $\mathrm{H} 0$ diterima

Tabel 3. Uji Autokorelasi

\begin{tabular}{|c|c|c|c|c|c|}
\hline \multicolumn{6}{|c|}{ Model Summary } \\
\hline Model & $\mathrm{R}$ & $\begin{array}{c}\mathrm{R} \\
\text { Square }\end{array}$ & $\begin{array}{c}\text { Adjusted } \\
\text { R } \\
\text { Square }\end{array}$ & $\begin{array}{c}\text { Std. } \\
\text { Error of } \\
\text { the } \\
\text { Estimate }\end{array}$ & $\begin{array}{l}\text { Durbin- } \\
\text { Watson }\end{array}$ \\
\hline 1 & $.995^{\mathrm{a}}$ & 0,991 & 0,988 & 0,05845 & 1,875 \\
\hline
\end{tabular}

\begin{tabular}{l} 
a. Predictors: (Constant), BOPO(X4), NPL(X1), \\
LDR(X3), NIM(X2) \\
\hline b. Dependent Variable: ROA(Y) \\
\hline
\end{tabular}

Sumber tabel : Data Penelitian,2021

Dari tabel 3. Uji Autokorelasi, untuk nilai du dicari distribusi nilai tabel durbin Watson berdasarkan $\mathrm{k}(4)$ dan $\mathrm{N}=18$ dengan signifikansi 5\%, kemudian du (1.872) < Durbin Watson $(1,875)<4$-du $(2,128)$ dapat disimpulkan bahwa ada kepastian tidak adanya gejala autokorelasi.

2. Uji Regresi Linier Berganda

Analisis linier berganda digunakan untuk memprediksi bagaimana keadaan (naik turunnya) variabel dependen, ketika dua atau lebih variabel independen sebagai faktor prediktor dimanipulasi (kenaikan dan penurunan nilai).

Tabel 4. Uji Regresi Linier Berganda

\begin{tabular}{|c|c|c|c|c|c|c|c|c|}
\hline \multicolumn{9}{|c|}{ Coefficients ${ }^{\mathrm{a}}$} \\
\hline \multirow[t]{2}{*}{$\begin{array}{l}\text { Mod } \\
\text { el }\end{array}$} & & & \multicolumn{2}{|c|}{\begin{tabular}{|l|} 
Standa \\
rdized \\
Coeffi \\
cients
\end{tabular}} & \multirow[t]{2}{*}{$\mathrm{t}$} & \multirow[t]{2}{*}{ Sig. } & \multirow{2}{*}{$\begin{array}{c}\text { Collin } \\
\text { earity } \\
\text { Statist } \\
\text { ics } \\
\begin{array}{c}\text { Tolera } \\
\text { nce }\end{array}\end{array}$} & \multirow[b]{2}{*}{ VIF } \\
\hline & & & & Beta & & & & \\
\hline 1 & $\begin{array}{l}\text { (Constan } \\
\text { t) }\end{array}$ & 5,482 & 0,405 & & 13,538 & 0,000 & & \\
\hline & $\begin{array}{l}\text { NPL(X1 } \\
\text { ) }\end{array}$ & $-0,012$ & 0,022 & $-0,016$ & $-0,521$ & 0,611 & 0,757 & 1,322 \\
\hline & NIM(X2 & 0,514 & 0,044 & 0,434 & 11,747 & 0,000 & 0,527 & 1,898 \\
\hline & $\begin{array}{l}\mathrm{LDR}(\mathrm{X} 3 \\
{ }^{2}\end{array}$ & 0,000 & 0,001 & $-0,012$ & $-0,406$ & 0,691 & 0,796 & 1,257 \\
\hline & $\begin{array}{l}\mathrm{BOPO}(\mathrm{X} \\
\text { 4) }\end{array}$ & $-0,082$ & 0,004 & $-0,734$ & $-23,131$ & 0,000 & 0,715 & 1,399 \\
\hline
\end{tabular}




\section{a. Dependent Variable: ROA(Y)}

\section{Sumber Tabel : Data Penelitian,2021}

Pada Tabel 4. Dari perhitungan menggunakan SPSS diperoleh hasil sebagai berikut: $\mathrm{a}=13,538 \mathrm{~b} 1=-0,521, \mathrm{~b} 2=11,747, \mathrm{~b} 3=-0,046, \mathrm{~b} 4=-23,131$

Berdasarkan rumus persamaan regresi linier berganda diperoleh hasil analisis sebagai berikut: $\mathrm{Y}=13,538+\{(-0,521) \mathrm{X} 1+11,747) \mathrm{X} 2+(-0,046) \mathrm{X} 3+(-23,131) \mathrm{X} 4\}$

Model persamaan regresi berganda signifikan:

Nilai analisis regresi linier berganda yang masih berupa angka dapat dijelaskan dalam bahasa yang mudah dipahami sebagai berikut:

a. Nilai $\alpha$ sebesar 13,538 artinya jika variabel NPL (X1) variabel NIM (X2), variabel LDR (X3) dan variabel $\mathrm{BOPO}(\mathrm{X} 4)$ konstan atau tidak berubah (sama dengan nol, maka tingkat kinerja keuangan (Y) akan menjadi senilai 13,538.

b. Nilai koefisien regresi $\mathrm{X} 1=-0,521$ menunjukkan bahwa jika risiko pembiayaan meningkat $100 \%$, maka akan mengakibatkan peningkatan kinerja keuangan pada PT Bank Pembangungan Daerah Jawa Timur sebesar -0,521.

c. Nilai koefisien regresi X2 $=11,747$ menunjukkan bahwa jika Net Interest Margin mengalami peningkatan sebesar $100 \%$, maka akan mengakibatkan peningkatan kinerja keuangan pada PT Bank Pembangungan Daerah Jawa Timur sebesar 11,747.

d. Nilai koefisien regresi X3 $=-0,046$ menunjukkan bahwa apabila Loan to Deposit Ratio mengalami peningkatan sebesar $100 \%$, maka akan mengakibatkan peningkatan kinerja keuangan pada PT Bank Pembangungan Daerah Jawa Timur sebesar -0,046.

e. Nilai koefisien regresi X3 $=-23,131$ menunjukkan bahwa apabila Belanja Operasional dari Pendapatan Operasional mengalami peningkatan sebesar 100\%, maka akan mengakibatkan peningkatan kinerja keuangan pada PT Bank Bank Pembangungan Daerah Jawa Timur sebesar $-23,131$.

3. Pengujian hipotesis

a. Uji Koefisien Determinan (R2)

Koefisien determinasi digunakan untuk mengetahui persentase hubungan antara variabel bebas dan variabel terikat. Besarnya persentase pengaruh semua variabel terhadap nilai variabel dependen dapat dilihat dari koefisien determinan (R2) persamaan regresi. Koefisien determinasi dilihat dari hasil perhitungan SPSS sebagai berikut:

Tabel 5. Uji Koefisien Determinan

\begin{tabular}{|c|c|c|c|c|c|}
\hline \multicolumn{6}{|c|}{ Model Summary ${ }^{b}$} \\
\hline Model & $\mathrm{R}$ & $\begin{array}{c}\mathrm{R} \\
\text { Square }\end{array}$ & $\begin{array}{c}\text { Adjusted } \\
\text { R } \\
\text { Square }\end{array}$ & $\begin{array}{c}\text { Std. } \\
\text { Error of } \\
\text { the } \\
\text { Estimate }\end{array}$ & $\begin{array}{l}\text { Durbin- } \\
\text { Watson }\end{array}$ \\
\hline 1 & $.995^{\mathrm{a}}$ & 0,991 & 0,988 & 0,05845 & 1,875 \\
\hline \multicolumn{6}{|c|}{$\begin{array}{l}\text { a. Predictors: (Constant), BOPO(X4), NPL(X1), } \\
\text { LDR(X3), NIM(X2) }\end{array}$} \\
\hline \multicolumn{6}{|c|}{ b. Dependent Variable: ROA(Y) } \\
\hline
\end{tabular}

Sumber data : Data Penelitian, 2021

Dilihat dari tabel 5, koefisien determinan (R2) menunjukkan angka Adjusted R Square sebesar 0,988 atau 98,8\% yang berarti variasi tingkat kinerja keuangan dapat dijelaskan oleh risiko pembiayaan, Net Interest Margin, Loan to Deposit Ratio dan Belanja Operasional dari Pendapatan Operasional, sisanya 1,2\% dapat dijelaskan dari variabel lain di luar variabel penelitian.

b. Uji Parsial (Uji t)

Uji t digunakan untuk menguji apakah masing-masing variabel independen (independen) secara individual maupun individual memiliki pengaruh yang signifikan terhadap variabel 
dependen pada tingkat signifikan 0,05 (5\%) dengan asumsi variabel bebas independen konstan.

Tabel 6. Uji Parsial

\begin{tabular}{|c|c|c|c|c|c|c|c|c|}
\hline \multicolumn{9}{|c|}{ Coefficients $^{\mathrm{a}}$} \\
\hline \multirow[t]{2}{*}{$\begin{array}{l}\text { Mod } \\
\text { el }\end{array}$} & & & & $\begin{array}{c}\text { Standa } \\
\text { rdized } \\
\text { Coeffi } \\
\text { cients }\end{array}$ & $\mathrm{t}$ & Sig. & $\begin{array}{c}\text { Collin } \\
\text { earity } \\
\text { Statist } \\
\text { ics } \\
\end{array}$ & \\
\hline & & & & Beta & & & $\begin{array}{c}\text { Tolera } \\
\text { nce }\end{array}$ & VIF \\
\hline \multirow[t]{5}{*}{1} & $\begin{array}{l}\text { (Constan } \\
\text { t) }\end{array}$ & 5,482 & 0,405 & & 13,538 & 0,000 & & \\
\hline & $\begin{array}{l}\text { NPL(X1 } \\
\text { ) }\end{array}$ & $-0,012$ & 0,022 & $-0,016$ & $-0,521$ & 0,611 & 0,757 & 1,322 \\
\hline & $\operatorname{NIM}(\mathrm{X} 2$ & 0,514 & 0,044 & 0,434 & 11,747 & 0,000 & 0,527 & 1,898 \\
\hline & $\mathrm{LDR}(\mathrm{X} 3$ & 0,000 & 0,001 & $-0,012$ & $-0,406$ & 0,691 & 0,796 & 1,257 \\
\hline & $\begin{array}{l}\mathrm{BOPO}(\mathrm{X} \\
\text { 4) }\end{array}$ & $-0,082$ & 0,004 & $-0,734$ & $-23,131$ & 0,000 & 0,715 & 1,399 \\
\hline
\end{tabular}

Sumber data: Data Rist,2021

pada Tabel 6. Hasil uji parsial dapat dilihat dengan melihat hasil koefisien keluaran SPSS, jika thitung > ttabel, maka artinya variabel bebas (x) secara parsial berpengaruh terhadap variabel terkait $(\mathrm{Y})$. Untuk rumus mencari Ttabel $=(\dot{\alpha} / 2 ; \mathrm{n}-\mathrm{k}-1)=(0,05 / 2 ; 18-4-$ $1)=(0,025 ; 13)=2.1604$, maka thitung $(13,538)>\operatorname{ttabel}(2.1604)$, maka variabel bebas secara parsial terdapat pengaruh pada variabel terkait. Untuk melihat secara parsial pengaruh variabel bebas terhadap tingkat kinerja keuangan pada PT Bank Pembangunan Daerah Jawa Timur, maka analisisnya sebagai berikut:

1) Pengaruh NPL (X1) terhadap tingkat $\mathrm{ROA}(\mathrm{Y})$ dari hipotesis:

H0: Risiko NPL(X1) parsial tidak berpengaruh signifikan terhadap tingkat ROA(Y) pada PT Bank Pembangunan Daerah Jawa Timur.

Ha: Risiko NPL(X1) secara parsial berpengaruh positif signifikan terhadap tingkat ROA(Y) pada PT Bank Pembangunan Daerah Jawa Timur.

Berdasarkan hasil uji t untuk variabel risiko pembiayaan diperoleh thitung -0,521 dan ttabel 2.1604 dengan nilai signifikan $0,611>0,05$ sehingga $\mathrm{HO}$ diterima dan $\mathrm{Ha}$ ditolak. Hal ini menunjukkan bahwa NPL(X1) tidak berpengaruh negatif signifikan secara parsial terhadap ROA(Y) pada PT Bank Pembangunan Daerah Jawa Timur.

2) Pengaruh $\mathrm{NIM}(\mathrm{X} 2)$ terhadap tingkat $\mathrm{ROA}(\mathrm{Y})$ hipotesis:

H0: Risiko NIM(X2) secara parsial tidak berpengaruh signifikan terhadap ROA(Y) PT Bank Bank Pembangunan Daerah Jawa Timur.

Ha: Risiko NIM(X2) secara parsial berpengaruh positif signifikan terhadap ROA(Y) PT Bank Pembangunan Daerah Jawa Timur.

Berdasarkan hasil uji t untuk variabel risiko operasional diperoleh thitung $\quad 11,747$ dan ttabel 2.1604 dengan nilai signifikansi $0,000<0,05$ sehingga H0 ditolak dan Ha diterima. Hal ini menunjukkan bahwa $\mathrm{NIM}(\mathrm{X} 2)$ berpengaruh positif signifikan secara parsial terhadap ROA(Y) pada PT Bank Pembangunan Daerah Jawa Timur.

3) Pengaruh Risiko LDR(X3) terhadap Tingkat ROA(Y). Hipotesis:

H0: Secara parsial Risiko LDR(X3) tidak berpengaruh signifikan terhadap Tingkat ROA(Y) PT Bank Pembangunan Daerah Jawa Timur.

Ha: Secara parsial Risiko LDR(X3) berpengaruh signifikan terhadap Tingkat ROA(Y) PT Bank Pembangunan Daerah Jawa Timur. 
Berdasarkan hasil uji t untuk variabel LDR(X3) diperoleh t hitung -0,406 dan t tabel 2.1604 dengan nilai signifikansi 0,691 > 0,05, maka H0 diterima dan Ha ditolak. Hal ini menunjukkan bahwa risiko LDR(X3) tidak berpengaruh negatif signifikan secara parsial terhadap tingkat ROA(Y) pada PT Bank Pembangunan Daerah Jawa Timur.

4) Pengaruh Risiko $\mathrm{BOPO}(\mathrm{X} 4)$ terhadap Tingkat $\mathrm{ROA}(\mathrm{Y})$. Hipotesis:

H0: Secara parsial Risiko $\mathrm{BOPO}(\mathrm{X} 4)$ tidak berpengaruh signifikan terhadap Tingkat ROA(Y) PT Bank Pembangunan Daerah Jawa Timur.

Ha: Secara parsial Risiko $\mathrm{BOPO}(\mathrm{X} 4)$ berpengaruh signifikan terhadap Tingkat ROA(Y) PT Bank Pembangunan Daerah Jawa Timur.

Berdasarkan hasil uji t untuk variabel $\mathrm{BOPO}(\mathrm{X} 4)$ diperoleh thitung -23,131 dan t tabel 2.1604 dengan nilai signifikansi $0,000<0,05$, maka H0 ditolak dan Ha diterima. Hal ini menunjukkan bahwa risiko $\mathrm{BOPO}(\mathrm{X} 4)$ berpengaruh negatif signifikan secara parsial terhadap tingkat ROA(Y) pada PT Bank Pembangunan Daerah Jawa Timur.

c. Uji Simultan (Uji f)

Uji f digunakan untuk mengetahui pengaruh risiko NPL, risiko NIM, risiko LDR dan risiko BOPO terhadap tingkat ROA bank. Uji f pada dasarnya menunjukkan apakah semua variabel bebas atau bebas yang dimasukkan dalam model memiliki pengaruh bersama terhadap variabel terikat atau terikat.

Dengan kriteria uji $\mathrm{F}$ tabel,sebagai berikut :

jika Fhitung < Ftabel maka H0 diterima dan Ha ditolak, artinya tidak signifikan jika Fhitung > Ftabel maka H0 ditolak dan Ha diterima, artinya signifikan.

Tabel 7. Uji Simultan (Uji f)

\begin{tabular}{|c|c|c|c|c|c|c|}
\hline \multicolumn{7}{|c|}{ ANOVA $^{\mathrm{a}}$} \\
\hline Model & & $\begin{array}{l}\text { Sum of } \\
\text { Squares }\end{array}$ & $\mathrm{df}$ & $\begin{array}{l}\text { Mean } \\
\text { Square }\end{array}$ & $\mathrm{F}$ & Sig. \\
\hline \multirow[t]{3}{*}{1} & Regression & 4,706 & 4 & 1,177 & 344,389 & $.000^{\mathrm{b}}$ \\
\hline & Residual & 0,044 & 13 & 0,003 & & \\
\hline & Total & 4,750 & 17 & & & \\
\hline \multicolumn{7}{|c|}{ a. Dependent Variable: $\mathrm{ROA}(\mathrm{Y})$} \\
\hline
\end{tabular}

Sumber tabel : Data Penelitian, 2021

Pada tabel 7, dari uji ANOVA atau uji F diperoleh nilai Fhitung 344,389 > F tabel 2.1604, dengan tingkat signifikan 0,000. Karena probabilitasnya signifikan maka jauh lebih kecil dari 0,05 sehingga $\mathrm{H} 0$ ditolak dan Ha diterima. Hal ini menunjukkan bahwa secara simultan terdapat pengaruh yang signifikan pada variabel bebas (NPL.NIM,FDR,BOPO) terhadap variabel terikat ROA untuk pengendalian kinerja keuangan pada PT Bank Pembangunan Daerah Jawa Timur.

\section{PEMBAHASAN}

Hasil dari pengolahan data penelitian manajemen risiko menunjukkan bahwa koefisien determinan (R2) menunjukkan angka Adjusted R Square sebesar 0,988 atau 98,8\% yang berarti variasi tingkat kinerja keuangan dapat dijelaskan oleh risiko pembiayaan, Net Interest Margin, Loan to Deposit Ratio dan Belanja Operasional dari Pendapatan Operasional, sisanya 1,2\% dapat dijelaskan dari variabel lain di luar variabel penelitian. Pada Pengaruh secara parsial untuk Risiko NPL(X1) tidak berpengaruh negatif secara signifikan parsial terhadap ROA(Y), untuk risiko $\mathrm{NIM}(\mathrm{X} 2)$ berpengaruh positif secara signifikan parsial terhadap ROA(Y), untuk risiko LDR(X3) tidak berpengaruh negatif secara signifikan parsial terhadap tingkat $\mathrm{ROA}(\mathrm{Y})$, dan untuk risiko $\mathrm{BOPO}(\mathrm{X} 4)$ berpengaruh negatif secara signifikan parsial terhadap tingkat $\mathrm{ROA}(\mathrm{Y})$. Hal ini menunjukkan bahwa secara simultan terdapat pengaruh yang signifikan pada variabel bebas (NPL.NIM,FDR,BOPO) terhadap variabel terikat ROA untuk pengendalian kinerja keuangan pada PT Bank Pembangunan Daerah Jawa Timur. Pada penelitian artikel sebelumnya i untuk 
mengetahui pengaruh Risiko Perbankan yang dianalisis dengan menggunakan Rasio NPL, NIM, LDR, BOPO terhadap kinerja keuangan pada Bank Pembangunan Daerah se- Indonesia, terdapat kesamaan untuk risiko $\mathrm{NIM}(\mathrm{X} 2)$ berpengaruh positif secara signifikan parsial terhadap ROA(Y) dan kesamaan hasil secara simultan terdapat pengaruh yang signifikan pada variabel bebas (NPL.NIM,FDR,BOPO) terhadap variabel terikat ROA.

\section{KESIMPULAN}

Kesimpulan pada penelitian majemen resiko diataranya, sebagai berikut :

1. Tingkat pengaruh nilai variable bebas(NPL,NIM,LDR,BOPO) adalah $98,8 \%$ terhadap variable terkait(ROA ), sisanya $1,2 \%$ dari variable lain yang belum masuk dalam penelitian tersebut.

2. Terdapat Pengaruh secara parsial positif pada variabel bebas untuk risiko NIM(X2) terhadap $\operatorname{ROA}(\mathrm{Y})$.

3. Hal ini menunjukkan bahwa secara simultan terdapat pengaruh yang signifikan pada variabel bebas (NPL.NIM,FDR,BOPO) terhadap variabel terikat ROA untuk pengendalian kinerja keuangan pada PT Bank Pembangunan Daerah Jawa Timur.

\section{REFERENSI}

Ardhariksa Zukhruf Kurniullah. (2021). Kewirausahaan dan Bisnis. Yayasan Kita menulis.

Danar Maharudin, A. (2019). Efisiensi Perbankan Syariah Di Indonesia. JEJAK: Jurnal Ekonomi Dan Kebijakan, 7(2), 1-11. https://doi.org/10.15294/jejak.v7i2.3895

Dewi, I. A. M. S. (2019). Manajemen Resiko. Retrieved from http://repo.unhi.ac.id/bitstream/123456789/184/1/ILMU ALAMIAH DASAR.pdf

Handa Gustiawan. (2019). Analisis Manajemen Risiko Operasional Pada Usaha Kue Dan Roti CV. Jaya Bakery Dalam Perspektif Ekonomi Islam. $A \gamma \alpha \eta, 8(5), 55$.

ILO. (2009). Manajemen Sumber Daya Manusia Manajemen Sumber Daya Manusia Untuk Kerjasama dan Usaha yang Sukses.

Indah Azhari, S. R., Junaid, A., \& Tjan, J. S. (2020). Pengaruh Kompetensi, Independensi, Dan Profesionalisme Auditor Terhadap Kualitas Audit Dengan Etika Auditor Sebagai Variabel Moderasi. Invoice : Jurnal Ilmu Akuntansi, 2(2), 139-184.

https://doi.org/10.26618/inv.v2i2.4116

Ismail. (2016). Perbankan Syariah. Karisma Putra Utama.

Iwan Hermawan. (2019). Metodologi Penelitian Pendidikan ( Kualitatif, Kuantitatif dan Mixed Method). Hidayatul Quran.

Kansil, D., Murni, S., Tulung, J. E., Risiko, P., Kansil, D., Murni, S., ... Roa, B. (2017). Pengaruh Risiko Perbankan Terhadap Kinerja Keuangan Tahun 2013-2015 (Bank Pembangunan Daerah Se-Indonesia). Jurnal EMBA: Jurnal Riset Ekonomi, Manajemen, Bisnis Dan Akuntansi, 5(3), 3508-3517. https://doi.org/10.35794/emba.v5i3.17581

Khasanah, I., \& Pertiwi, O. D. (2010). terhadap Kepuasan Konsumen RS St . Elisabeth Semarang. Jurnal Khasanah Pertiwi, 12(2), 117-124.

Lepar, F. R., Mandagi, R. J. M., \& Lumeno, S. S. (2018). Model Risiko Pada Tahapan Pelaksanaan Pembangunan Proyek Bangunan Swasta Yang Berpengaruh Terhadap Kinerja Proyek. Jurnal Sipil Statik, 6(2), 127.

Manik, S. (2017). Pengaruh Kepuasan Kerja Terhadap Disiplin Kerja Pegawai Kantor Camat Pendalian Iv Koto Kabupaten Rokan Hulu. International Journal of Social Science and Business, 1(4), 257. https://doi.org/10.23887/ijssb.v1i4.12526

Nazir, R., \& Mahfuzah, N. (2018). The Effect of Risk Management Implementation on Financial Performance Satisfaction at Regional Development Banks in Indonesia. Jurnal Visioner \& Strategis, 7(1), 41-50.

OJK, T. (2021). Otoritas jasa Keuangan. Retrieved from web page website: https://www.ojk.go.id/id/Default.aspx

Probowati, D. E. P. (2020). Baitul Maal at Tanwil Sebagai Lembaga Intermediasi dan Perannya dalam Mereduksi Lintah Darat. Ecobankers: Journal of ..., 1, 59-78. Retrieved from http://journal.bungabangsacirebon.ac.id/index.php/EcoBankers/article/view/73 
Purwanto, H. (2016). Pengaruh Kesehatan Bank Terhadap Pertumbuhan Laba Pada Perusahaan Bank Go-Publik di Bursa Efek Indonesia. Journal of Chemical Information and Modeling, 53(9), 1689-1699.

Rahadjeng, E. R. (2017). "Pengaruh Perputaran Piutang dan Pengumpulan Piutang Terhadap Likuiditas Perusahaan Otomotif dan Komponen yang Tercatat di Bursa Efek Indonesia." Seminar Nasional Dan Gelar Produk, 1094-1103.

Ridha, N. (2017). Proses Penelitian, Masalah, Variabel, dan Paradigma Penelitian. Jurnal Hikmah, 14(1), 62-70. Retrieved from http://jurnalhikmah.staisumateramedan.ac.id/index.php/hikmah/article/download/10/13

Solissa, D. N. (2017). Profit Equalization Reserve (PER) Sebagai Upaya Mitigasi Risiko Imbal Hasil Perbankan Syari'ah (Suatu Kajian dengan Pendekatan Maqasid asy-Syari'ah). Az Zarqa', 9(1), 147-168.

Suci Izdihar, A. H. dan N. A. (2017). Pengaruh Penerapan Manajemen Risiko Terhadap Kinerja Keuangan Dengan Dimoderasi Good Corporate Governance (Studi Empiris Pada BPD SeIndonesia Tahun 2009-2013 ). JURNAL EKONOMI, 25, 1-14.

Sukmawati, N., \& Purbawangsa, I. (2016). Pengaruh Pertumbuhan Dana Pihak Ketiga, Pertumbuhan Kredit, Risiko Kredit, Likuiditas, Dan Kondisi Ekonomi Terhadap Profitabilitas. None, 5(9), 248723.

Suryani. (2018). Pengaruh Sistem Pengendalian Intern Terhadap Kualitas Laporan Keuangan Pada Pt. Pulau Sambu Kuala Enok. Akuntnasi Dan Keuangan, 7, 18.

Suwinardi. (2016). Manajemen risiko proyek. Orbith, 12(manajemen resiko proyek), 145-151.

Zainuddin. (2016). Pengaruh car, bopo, dan npf terhadap profitabilitas (roa) pada pt. Bank Rakyat Indonesia Syariah (Bri Syariah). Retrieved from IAIN Padang Sidempuan website: http://etd.iain-padangsidimpuan.ac.id/687/

Zubaidi, Z., Studi, P., Dan, K., Islam, P., Islam, U., \& Utara, N. (2018). Perencanaan Komunikasi Badan Penanggulangan Bencana Daerah ( Bpbd) Dalam Mengurangi Risiko Bencana Di Kota Medan. 103-115.

Zuhri, M. (2018). Pengendalian Risiko Hukum dalam Pemberian Kredit oleh Bank Umum. Jurnal Ilmiah Skylandsea, 2(1), 1-10. 